\title{
Silicon Fertilizer Application Promotes Phytolith Accumulation in Rice Plants
}

\author{
Xing Sun 1,2, Qin Liü ${ }^{1 *}$, Tongtong Tang ${ }^{1}$, Xiang Chen ${ }^{1}$ and Xia Luo ${ }^{2}$ \\ ${ }^{1}$ Institute of Soil Science, Chinese Academy of Sciences, Nanjing, China, ${ }^{2}$ School of Biological Science and Food \\ Engineering, Chuzhou University, Chuzhou, China
}

In this study, a pot experiment was designed to elucidate the effect of varying dosages of silicon (Si) fertilizer application in Si-deficient and enriched paddy soils on rice phytolith and carbon $(\mathrm{C})$ bio-sequestration within phytoliths (PhytOC). The maximum Si fertilizer dosage treatment (XG3) in the Si-deficit paddy soil resulted in an increase in the rice phytolith content by $100.77 \%$ in the stem, $29.46 \%$ in the sheath and $36.84 \%$ in the leaf compared to treatment without Si fertilizer treatment (CK). However, the maximum Si fertilizer dosage treatment (WG3) in the Si -enriched soil increased the rice phytolith content by only $32.83 \%$ in the stem, $27.01 \%$ in the sheath and $32.06 \%$ in the leaf. Overall, Si fertilizer application significantly $(p<0.05)$ increased the content of the rice phytoliths in the stem, leaf and sheath in both the Si-deficient and enriched paddy soils, and the statistical results showed a positive correlation between the amount of

OPEN ACCESS

Edited by:

Zhaoliang Song,

Tianjin University, China

Reviewed by:

Xinxin Zuo,

Fujian Normal University, China Yong $\mathrm{Ge}$,

Institute of Vertebrate Paleontology and Paleoanthropology (CAS), China

*Correspondence:

Qin Liu

qliu@issas.ac.cn

Specialty section:

This article was submitted to Functional Plant Ecology,

a section of the journal

Frontiers in Plant Science

Received: 12 December 2018

Accepted: 21 March 2019

Published: 16 April 2019

Citation:

Sun X, Liu Q, Tang T, Chen X and Luo X (2019) Silicon Fertilizer Application Promotes Phytolith Accumulation in Rice Plants.

Front. Plant Sci. 10:425. doi: 10.3389/fp/s.2019.00425
Si fertilizer applied and the rice phytolith content, with correlation coefficients of 0.998 $(p<0.01)$ in the Si-deficient soil and $0.952(p<0.05)$ in the Si-enriched soil. In addition, the existence of phytoliths in the stem, leaf, and sheath of rice and its content in the Si-enriched soil were markedly higher than that in the Si-deficient soil. Therefore, Si fertilizer application helped to improve the phytolith content of the rice plant.

Keywords: Si fertilizer, phytolith accumulation, Si-deficient paddy soils, PhytOC, rice organs

\section{INTRODUCTION}

Phytoliths derive from bio-mineralization in plants and usually take the shape of the plant cell or cell spatium where $\mathrm{Si}$ is deposited. The phytolith content of plants ranges from less than $50 \mathrm{~g} \mathrm{~kg}^{-1}$ to as high as $150 \mathrm{~g} \mathrm{~kg}^{-1}$ (Epstein, 1994; Parr et al., 2010; Song et al., 2013, 2017; Ji et al., 2017), mainly due to phylogenetic differences in Si requirements of most dicotyledons and some Gramineae (Hodson et al., 2005), as well as the amount of available silica in the environment (Seyfferth et al., 2013; Guo et al., 2015; Si et al., 2018; Wen et al., 2018).

Rice is a staple crop, with a global planting area of approximately $1.64 \times 10^{8}$ ha as of 2014 (Prajapati et al., 2016). When rice is harvested, the rice straw and husks are removed from the paddy field and used for other purposes, including animal feeding and firewood, or simply incinerated (Savant et al., 1996). Thus, most of the Si taken up by rice is removed from a field when the rice straw is removed, and the loss of $\mathrm{SiO}_{2}$ is from 75 to $130 \mathrm{~kg} \mathrm{hm}^{-2}$ every production season (Zhang et al., 2014). Such large losses of Si make it difficult to maintain the balance of $\mathrm{Si}$ in soils from natural weathering alone. Currently, most paddy soils in China are Si-deficient. For example, $73 \%$ of paddy soils in Zhejiang Province and approximately 60\% in Henan Province are Si-deficient (Cai, 2015). Some research has shown that Si fertilizer application can significantly increase the biomass of rice (Wu et al., 2014; Zhang et al., 2014). 
In plants, monosilicic acid is taken up from the soil by a specific transporter (Ma et al., 2006; Song et al., 2014a) and deposited throughout the cellular structures, thereby forming amorphous Si particles known as "phytoliths" (Piperno, 1988; Pearsall, 1989). There is a significant correlation between the Si content and the phytolith content of crop materials, including the leaves, stems and sheaths, and the Si concentration of the plant phytoliths is approximately $90 \%$ (Song et al., 2014a).

Phytoliths can occlude small amounts of many elements, such as C, N, S, and so on (Kameník et al., 2013; Li et al., 2014; Anala and Nambisan, 2015). The C-occluded content of phytoliths ranges from less than $1 \mathrm{~g} \mathrm{~kg}^{-1}$ to as high as $100 \mathrm{~g}$ $\mathrm{kg}^{-1}$ (Clarke, 2003). This PhytOC can be stored in the soil for thousands of years (Parr and Sullivan, 2005). Thus, it plays a vital role in global carbon (C) pools (Song et al., 2014a). The Si cycle is tightly coupled to the $\mathrm{C}$ cycle, and this interaction is relevant for research on climate change (Chadwick et al., 1994). The formation of phytoliths in rice plants depends not only on the crops (Li et al., 2013a; Guo et al., 2015) but also on the plant cultivars (Hodson et al., 2005; Henriet et al., 2008; Yang et al., 2015), the soil's Si availability (Henriet et al., 2008; Klotzbücher et al., 2018) and so on.

The application of Si fertilizer in soils with different available Si contents needs further study regarding the accumulation of phytoliths in rice. Thus, in this work, we designed a pot experiment to elucidate the effect of varying dosages of $\mathrm{Si}$ fertilizer application on the rice phytolith and PhytOC contents of plants grown in Si-deficient and enriched paddy soils.

\section{MATERIALS AND METHODS}

\section{Experimental Soils and Rice Cultivar}

The Si-deficient paddy soil (red paddy soil) was obtained from Yangliu Town, Xuanchen City, Anhui Province, China. The Si-enriched paddy soil (Wushan soils) was obtained from the Changshu Agroecological Experimental Station, Chinese Academy of Sciences. The base is located in Xinzhuang County, South Changshu, Suzhou, Jiangsu Province, China. The physicochemical properties of the two soils are shown in Table $\mathbf{1}$.

The rice cultivar (Oryza sativa) Nanjing 46 was obtained from the Changshu Agroecological Experimental Station, Chinese Academy of Sciences.

\section{Pot Experiment}

Two soils (Si-deficient and enriched paddy soils) were selected from Xuanchen City and the Changshu Agroecological Experimental Station, Chinese Academy of Sciences, respectively. Four available Si dosages were designed in the pot experiments: (1) CK (Si fertilizer not applied); (2) low slag Si fertilizer I $\left(\mathrm{SiO}_{2} 150 \mathrm{~kg} \mathrm{ha}^{-1}\right)$; (3) high slag Si fertilizer II (300 kg ha-1); and (4) high slag Si fertilizer III $\left(600 \mathrm{~kg} \mathrm{ha}^{-1}\right)$. Thus, this experiment comprised 8 treatments repeated 3 times. Two soils were placed in the pot bowl for a total volume of $0.0175 \mathrm{~m}^{3}$; each pot contained $\mathrm{N} 46 \%, \mathrm{P}_{2} \mathrm{O}_{5} 13.5 \%$, and $\mathrm{K}_{2} \mathrm{O} 60 \%$, Si fertilizer was applied as the base fertilizer and three rice plants were planted in every pot. Pots were placed in the greenhouse of the Changshu Agroecological Experimental Station, Chinese Academy of Sciences in June 2014, and the whole rice growth period was maintained using conventional management.

\section{Sample Preparation}

After the rice cultivar harvest, each rice plant was separated into five different organs: sheath, leaf, root, stem, and grain. All rice samples were rinsed twice in distilled water, placed in an ultrasonic bath for $20 \mathrm{~min}$ and subsequently dried in oven at $70^{\circ} \mathrm{C}$ for $24 \mathrm{~h}$. After hulling, the rice organ samples were stored for phytolith extraction and PhytOC determination.

\section{Phytolith Extraction From Rice Organs and PhytOC Analysis}

The phytolith extraction was used for a revised wet digestion measurement previously described by Zuo and Lü (2011); Sun et al. (2016). Phytolith extraction sample assemblages were installed on glass slides in Balsam Canada mounting medium. The slides were viewed at $400 \times$ magnification using a microscope (Jiangnan XP-213, China) fitted with a polarizing filter and a 5.0 MP color CCD camera to ensure the absence of organic material residue as shown by Parr et al. (2010; Figure 1). The PhytOC was measured using an Elemental Analyzer 3000 (GmbH Company, Germany).

\section{Statistical Analyses}

The mean values of all parameters were calculated from the determination of three replicates, and the standard errors of the means were determined. A one-way ANOVA was used to measure the significance of the results between different varieties, and Tukey's multiple range tests $(p<0.05)$ were subsequently performed. All the statistical analyses were performed using SPSS v.17 for Windows.

\section{RESULTS}

\section{Phytolith and C Contents of the Phytoliths in the Rice Organs}

With an increase in the application of the Si fertilizer dosages, the content of the phytoliths in the rice organs was increased in the Si-deficient red paddy soil (Table 2). For example, the content of the phytoliths in the XG3 $\left(26.10 \mathrm{~g} \mathrm{~kg}^{-1}\right)$ and XG2 $\left(18.50 \mathrm{~g} \mathrm{~kg}^{-1}\right)$ stems was significantly $(p<0.05)$ higher than that of the control $\left(13.00 \mathrm{~g} \mathrm{~kg}^{-1}\right)$, and the rate increased by 100.7 and $42.3 \%$, respectively. In addition, the content of the phytoliths of XG1 in the stem was not significantly $(p>0.05)$ different than that of the control. However, the content of the phytoliths in the rice sheath and leaf could be significantly $(p<0.05)$ increased by the application of all the Si fertilizer dosages. The content of the phytoliths in the XG3 treatment rice grains could only be increased by a high dose of Si fertilizer application. However, the content of the phytoliths in all the root treatments was not significantly $(p>0.05)$ different from that of the control. 
TABLE 1 | Basic chemical properties of the two soils.

\begin{tabular}{|c|c|c|c|c|c|c|c|c|}
\hline Experimental Soils & $\begin{array}{c}\mathrm{NH}_{4} \mathrm{OAC}- \\
\text { extractable } \\
\mathrm{Si}\left(\mathrm{mg} \mathrm{kg}^{-1}\right)\end{array}$ & $\mathrm{pH}$ & $\begin{array}{r}\text { Total N } \\
\left(\mathbf{g ~ k g}^{-1}\right)\end{array}$ & $\begin{array}{c}\text { Total P } \\
\left(\mathbf{g ~ k g}^{-1}\right)\end{array}$ & $\begin{array}{c}\text { Total K } \\
\left(\mathbf{g ~ k g}^{-1}\right)\end{array}$ & $\begin{array}{c}\text { Organic } \\
\text { matter } \\
\left(\mathrm{mg} \mathrm{kg}^{-1}\right)\end{array}$ & $\begin{array}{c}\mathrm{Na}_{2} \mathrm{CO}_{3}- \\
\text { extractable } \\
\mathrm{P}\left(\mathrm{mg} \mathrm{kg}^{-1}\right)\end{array}$ & $\begin{array}{c}\mathrm{NH}_{4} \mathrm{OAc}- \\
\text { extractable } \mathrm{K} \\
\left(\mathrm{mg} \mathrm{kg}^{-1}\right)\end{array}$ \\
\hline Si-deficient paddy soil (red paddy soil) & 5.67 & 4.62 & 1.20 & 0.18 & 52.49 & 28.89 & 17.44 & 210.0 \\
\hline Si-enriched paddy soil (Wushan soils) & 252.3 & 7.54 & 2.40 & 0.73 & 20.16 & 39.89 & 34.27 & 101.7 \\
\hline
\end{tabular}

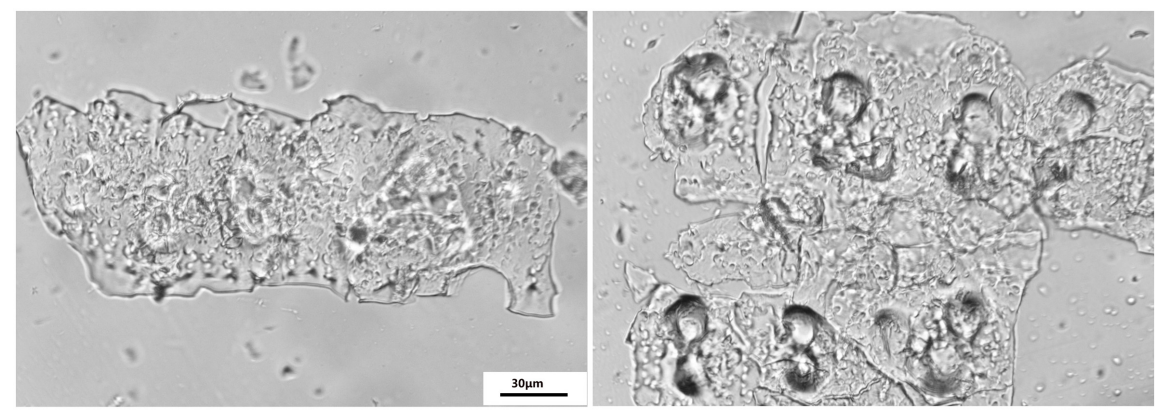

FIGURE 1 | Optical microscope images of phytoliths extracted from the rice samples using the wet ashing method according to Zuo and Lü (2011) and Sun et al. (2016); magnification 400×, scale bar $30 \mu \mathrm{m}$.

TABLE 2 | Different effects of silicon fertilizers on rice organs content of phytoliths.

\begin{tabular}{|c|c|c|c|c|c|}
\hline Treatments & stem $\left(\mathbf{g ~ k g}{ }^{-1}\right)$ & sheath $\left(\mathbf{g ~ k g}{ }^{-1}\right)$ & leaf $\left(\mathrm{g} \mathrm{kg}^{-1}\right)$ & grain $\left(\mathrm{g} \mathrm{kg}^{-1}\right)$ & $\operatorname{root}\left(\mathrm{g} \mathrm{kg}^{-1}\right)$ \\
\hline XCK & $13.00 \pm 1.44 c$ & $36.01 \pm 1.45 c$ & $34.72 \pm 1.50 c$ & $11.59 \pm 2.41 b$ & $80.66 \pm 25.81 a$ \\
\hline$X G 1$ & $16.84 \pm 1.07 \mathrm{bc}$ & $42.73 \pm 2.74 b$ & $41.37 \pm 2.25 b$ & $13.86 \pm 1.61 b$ & $117.20 \pm 18.58 a$ \\
\hline XG2 & $18.50 \pm 0.91 b$ & $49.37 \pm 0.89 a$ & $48.72 \pm 2.09 a$ & $12.96 \pm 3.49 b$ & $92.87 \pm 36.86 a$ \\
\hline XG3 & $26.10 \pm 4.41 a$ & $46.62 \pm 2.38 a$ & $47.51 \pm 3.08 a$ & $19.37 \pm 1.38 a$ & $84.78 \pm 30.35 a$ \\
\hline WCK & $37.22 \pm 4.19 b$ & $75.31 \pm 4.68 b c$ & $76.18 \pm 4.44 b$ & $16.60 \pm 3.29 b$ & $67.46 \pm 22.70 b$ \\
\hline WG1 & $38.57 \pm 4.63 b$ & $74.18 \pm 3.21 c$ & $76.14 \pm 8.10 b$ & $17.26 \pm 1.92 b$ & $56.09 \pm 1.76 b$ \\
\hline WG2 & $42.09 \pm 3.23 b$ & $84.00 \pm 5.19 b$ & $93.13 \pm 11.68 a$ & $21.69 \pm 1.83 \mathrm{ab}$ & $96.66 \pm 14.10 a$ \\
\hline WG3 & $49.44 \pm 0.74 a$ & $95.72 \pm 5.59 \mathrm{a}$ & $100.60 \pm 7.98 a$ & $24.72 \pm 4.96 \mathrm{a}$ & $82.03 \pm 5.32 \mathrm{ab}$ \\
\hline
\end{tabular}

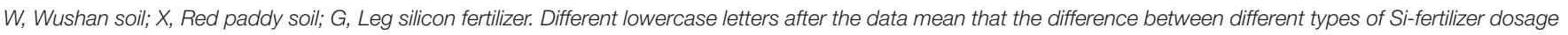
treatments are significant $(p<0.05)$.

With the increase in the application of the Si fertilizer doses, the content of the phytolith in the rice organs could be increased in the Si-enriched Wushan paddy soil (Table 2). For example, the content of the phytoliths of the WG3 $\left(100.60 \mathrm{~g} \mathrm{~kg}^{-1}\right)$ and WG2 (93.13 $\left.\mathrm{g} \mathrm{kg}^{-1}\right)$ leaves was significantly $(p<0.05)$ higher than that of the control $\left(76.18 \mathrm{~g} \mathrm{~kg}^{-1}\right)$, and the increase in the rate was 32.06 and $22.25 \%$, respectively. In addition, the content of the phytoliths of WG1 in the stem was not significantly $(p>0.05)$ different from that of the control. However, the content of the phytoliths in the other rice organs could be significantly $(p<0.05)$ increased by the application of high $\mathrm{Si}$ fertilizer dosages.

Thus, different Si fertilizer doses might increase the content of the phytoliths in the rice organs in either Si-deficient red paddy soil or Si-enriched Wushan paddy soil. The C content in the phytoliths in the organs was not affected by the increase in the $\mathrm{Si}$ fertilizer dose. However, the content of the $\mathrm{C}$ in the phytoliths was different in all the organs. Generally the content of the $\mathrm{C}$ of the leaf phytoliths was higher than that of the other organs (Table 3).

\section{Phytolith Content and the Estimated PhytOC Fluxes in Whole Rice Plants}

Compared with the control treatment, the content of phytoliths in the whole rice plant was significantly $(p<0.05)$ increased by the use of a high Si fertilizer dose in the two types of soils (Table 4). The $\mathrm{C}$ content of the phytoliths and the PhytOC content of the dry organ weights were not significantly $(p>0.05)$ different in the rice plant. In Si-deficient red paddy soil, the estimated PhytOC fluxes were calculated by the content and proportion of the phytoliths and the $\mathrm{C}$ content of the phytoliths in each part of the rice plant. The results showed that the application of Si fertilizer could significantly $(p<0.05)$ increase the content of the estimated PhytOC fluxes in the whole plant with the increase in the $\mathrm{Si}$ fertilizer dosage. The estimated PhytOC fluxes of the XG2 (11.36 kg-CO $\mathrm{ha}^{-1}$ year $\left.{ }^{-1}\right)$ and XG3 (12.93 kg-CO $\mathrm{ha}^{-1}$ year ${ }^{-1}$ ) treatments were 43.04 and $49.70 \%$, respectively, and were significantly $(p<0.05)$ higher than those of the control treatment $\left(8.41 \mathrm{~kg}-\mathrm{CO}_{2} \mathrm{ha}^{-1}\right.$ year $\left.{ }^{-1}\right)$. In the Si-enriched soil, the phytolith content of all the Si fertilizer 
TABLE 3 | Different effects of silicon fertilizers on rice organs content of $C$ content of phytoliths.

\begin{tabular}{|c|c|c|c|c|c|}
\hline Treatments & stem $\left(\mathbf{g ~ k g}{ }^{-1}\right)$ & sheath $\left(\mathrm{g} \mathrm{kg}^{-1}\right)$ & leaf $\left(\mathbf{g ~ k g}^{-1}\right)$ & grain $\left(\mathrm{g} \mathrm{kg}^{-1}\right)$ & $\operatorname{root}\left(\mathrm{g} \mathrm{kg}^{-1}\right)$ \\
\hline XCK & $8.60 \pm 1.34 a$ & $5.80 \pm 0.75 a$ & $8.02 \pm 1.81 a$ & $4.78 \pm 0.61 a$ & $1.67 \pm 0.01 a$ \\
\hline$X \mathrm{X} 1$ & $4.85 \pm 1.20 b$ & $6.09 \pm 0.92 a$ & $9.21 \pm 3.84 a$ & $6.79 \pm 1.87 a$ & $1.88 \pm 0.31 a$ \\
\hline XG2 & $5.28 \pm 1.20 b$ & $4.82 \pm 1.20 \mathrm{a}$ & $9.47 \pm 1.75 a$ & $7.08 \pm 1.43 a$ & $1.68 \pm 0.24 a$ \\
\hline XG3 & $4.64 \pm 0.38 b$ & $4.61 \pm 0.97 a$ & $7.23 \pm 1.20 \mathrm{a}$ & $5.10 \pm 1.90 \mathrm{a}$ & $2.19 \pm 0.34 a$ \\
\hline WCK & $2.28 \pm 0.36 a$ & $2.28 \pm 0.39 a b$ & $7.41 \pm 2.81 \mathrm{a}$ & $6.53 \pm 2.91 a$ & $4.98 \pm 1.42 a$ \\
\hline WG1 & $2.59 \pm 0.55 a$ & $2.16 \pm 0.11 \mathrm{ab}$ & $3.22 \pm 0.82 a$ & $3.39 \pm 0.45 a$ & $4.79 \pm 2.22 a$ \\
\hline WG2 & $4.13 \pm 2.0 \mathrm{a}$ & $2.82 \pm 0.54 a$ & $5.58 \pm 3.37 a$ & $4.34 \pm 0.92 a$ & $4.68 \pm 0.59 a$ \\
\hline WG3 & $2.23 \pm 0.67 a$ & $1.90 \pm 0.09 b$ & $4.31 \pm 2.57 a$ & $4.42 \pm 1.18 \mathrm{a}$ & $4.03 \pm 1.12 a$ \\
\hline
\end{tabular}

W, Wushan soil; X, Red paddy soil; G, Leg silicon fertilizer. Different lowercase letters after the data mean that the difference between different types of Si-fertilizer dosage treatments is significant $(p<0.05)$.

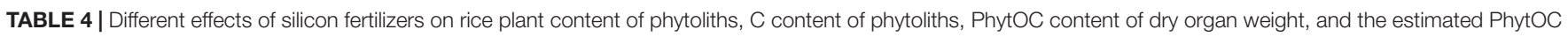
fluxes per ha in $\mathrm{kg}$ of $\mathrm{CO}_{2}$ equivalents $\left(\mathrm{kg} \sim \mathrm{e} \sim \mathrm{CO}_{2}\right)$ for rice.

\begin{tabular}{|c|c|c|c|c|c|}
\hline Treatments & $\begin{array}{c}\text { Phytolith } \\
\text { content }\left(\mathrm{g} \mathrm{kg}^{-1}\right)\end{array}$ & $\begin{array}{c}\text { C content of } \\
\text { phytoliths }\left(\mathrm{g} \mathrm{kg}^{-1}\right)\end{array}$ & $\begin{array}{l}\text { PhytOC content of dry } \\
\text { organs weight }\left(\mathrm{g} \mathrm{kg}^{-1}\right)\end{array}$ & $\begin{array}{l}\text { Estimated PhytOC fluxes } \\
\left(\mathrm{kg}-\mathrm{CO}_{2} \mathrm{ha}^{-1} \mathrm{yr}^{-1}\right)\end{array}$ & Biomass $\left(t \mathrm{ha}^{-1}\right)$ \\
\hline XCK & $24.23 \pm 0.39 b$ & $5.74 \pm 0.52 a$ & $0.13 \pm 0.01 b$ & $8.41 \pm 0.99 b$ & $16.38 \pm 2.34 b$ \\
\hline$X \mathrm{X} 1$ & $26.64 \pm 1.02 \mathrm{a}$ & $6.61 \pm 1.48 \mathrm{a}$ & $0.16 \pm 0.04 a$ & $10.38 \pm 2.43 a$ & $18.43 \pm 1.74 a$ \\
\hline XG2 & $28.32 \pm 2.06 a$ & $6.56 \pm 1.04 a$ & $0.17 \pm 0.03 a$ & $11.36 \pm 2.34 a$ & $18.90 \pm 1.67 a$ \\
\hline XG3 & $31.94 \pm 2.18 a$ & $5.14 \pm 1.05 a$ & $0.16 \pm 0.03 a$ & $12.93 \pm 0.54 a$ & $20.33 \pm 0.77 a$ \\
\hline WCK & $34.96 \pm 0.88 b$ & $5.44 \pm 1.80 a$ & $0.17 \pm 0.05 a$ & $8.74 \pm 0.29 a$ & $17.94 \pm 0.46 a$ \\
\hline WG1 & $36.22 \pm 1.06 b$ & $3.21 \pm 0.15 a$ & $0.11 \pm 0.01 a$ & $7.92 \pm 0.95 a$ & $17.42 \pm 1.61 a$ \\
\hline WG2 & $48.06 \pm 4,34 a$ & $4.29 \pm 1.09 a$ & $0.21 \pm 0.08 a$ & $11.11 \pm 1.93 a$ & $17.78 \pm 4.38 \mathrm{a}$ \\
\hline WG3 & $53.85 \pm 0.79 a$ & $4.39 \pm 0.68 a$ & $0.21 \pm 0.07 a$ & $9.23 \pm 0.09 a$ & $14.76 \pm 1.78 b$ \\
\hline
\end{tabular}

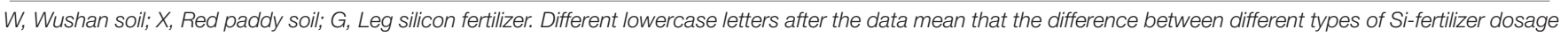
treatments are significant $(p<0.05)$.

treatments in the rice plants was higher than that of the control treatment, but it was not significantly $(p>0.05)$ different in all the Si fertilizer treatments compared with the control treatment. The estimated PhytOC fluxes of WG1 were 1.3\% lower than those of the control.

\section{The Correlation Coefficients Between the Six Variables of the Red Paddy Soil}

As shown in Table 5, the coefficient of variation in the different factors in the Si-deficient red paddy soils was high, illustrating considerable variation among these different Si fertilizer dosages. The results demonstrated that there was a significant correlation ( $R=0.998$ and $p<0.01$ ) between the phytolith content and the Si fertilizer dose. The $\mathrm{C}$ contents of the phytoliths were not correlated $(R=-0.177$ and $p>0.05)$ with the phytolith content in the rice plants treated with different fertilizer doses. The correlation coefficient was 0.986 , indicating a significant relationship $(p<0.05)$ between the phytolith content and the estimated PhytOC fluxes. The biomass of the rice was significantly related to the phytolith content $(R=0.972$ and $p<0.05)$ and the estimated PhytOC fluxes $(R=0.994$ and $p<0.01)$.

\section{The Correlation Coefficients Between the Six Variables of the Wushan Soil}

As shown in Table 6, the coefficient of variation in the different factors in the Si-deficient red paddy soils was high, illustrating considerable variation among the different Si fertilizer doses. The results demonstrated that there was a significant correlation ( $R=0.952$ and $p<0.05)$ between the phytolith content and the Si fertilizer dose. The $\mathrm{C}$ contents of the phytoliths were not correlated $(R=-0.035$ and $p>0.05)$ with the phytolith content in the rice plants of different fertilizer treatments. The correlation coefficient was 0.598 and there was significant correlation $(p>0.05)$ between the phytolith content and the estimated PhytOC fluxes. The biomass of the rice was significantly correlated with the phytolith content $(R=-0.890$ and $p>0.05)$ and the estimated PhytOC fluxes $(R=0.076$ and $p>0.05)$.

\section{DISCUSSION}

Rice accumulates Si (Seyfferth et al., 2013), and the Si concentration is approximately $10-15 \%$ in the rice plant (Marschner, 1995), with approximately $90 \%$ of the Si present in the phytolith (Wang, 1998). There was a significant correlation between the Si content and the phytolith content of the crop materials, such as the phytolith contents of the rice leaves, stems and sheaths (Song et al., 2014a). The shape of the phytoliths in the different rice organs varied (e.g., double-peaked, bulliform, and parallel dumbbell phytoliths) (Prajapati et al., 2016). Prajapati et al. (2016) reported that the phytolith content in the different rice organs (stem, sheath, leaf, and grain) ranged from 0.14 to $26.4 \mathrm{~g} \mathrm{~kg}^{-1}$. Similar results and trends were reported by other 
TABLE 5 | The correlation coefficients between the six variables of the red paddy soil.

\begin{tabular}{|c|c|c|c|c|c|c|}
\hline Variables & $\begin{array}{l}\text { Silicon } \\
\text { fertilizer }\end{array}$ & $\begin{array}{l}\text { Phytolith } \\
\text { content }\end{array}$ & $\begin{array}{l}\text { C content of } \\
\text { phytoliths }\end{array}$ & $\begin{array}{l}\text { PhytOC content of } \\
\text { dry organs weight }\end{array}$ & $\begin{array}{c}\text { Estimated } \\
\text { PhytOC } \\
\text { fluxes }\end{array}$ & Biomass \\
\hline Silicon fertilizer & 1 & & & & & \\
\hline Phytolith content & $0.998^{* *}$ & 1 & & & & \\
\hline C content of phytoliths & -0.238 & -0.177 & 1 & & & \\
\hline PhytOC content of dry organs weight & 0.620 & 0.665 & 0.612 & 1 & & \\
\hline Estimated PhytOC fluxes & $0.973^{*}$ & $0.986^{*}$ & -0.008 & 0.795 & 1 & \\
\hline Biomass & 0.953* & $0.972 *$ & 0.041 & 0.799 & $0.994^{* *}$ & 1 \\
\hline
\end{tabular}

*Correlation is significant at the 0.05 level (2-tailed). ${ }^{* *}$ Correlation is significant at the 0.01 level (2-tailed).

TABLE 6 | The correlation coefficients between the six variables of the Wushan soil.

\begin{tabular}{|c|c|c|c|c|c|c|}
\hline Variables & $\begin{array}{l}\text { Silicon } \\
\text { fertilizer }\end{array}$ & $\begin{array}{l}\text { Phytolith } \\
\text { content }\end{array}$ & $\begin{array}{l}\text { C content of } \\
\text { phytoliths }\end{array}$ & $\begin{array}{l}\text { PhytOC content of } \\
\text { dry organs weight }\end{array}$ & $\begin{array}{c}\text { Estimated } \\
\text { PhytOC } \\
\text { fluxes }\end{array}$ & Biomass \\
\hline Silicon fertilizer & 1 & & & & & \\
\hline Phytolith content & $0.952 *$ & 1 & & & & \\
\hline C content of phytoliths & -0.209 & -0.035 & 1 & & & \\
\hline PhytOC content of dry organs weight & 0.599 & 0.796 & 0.526 & 1 & & \\
\hline Estimated PhytOC fluxes & 0.333 & 0.598 & 0.229 & 0.800 & 1 & \\
\hline Biomass & -0.890 & -0.746 & 0.100 & -0.393 & 0.076 & 1 \\
\hline
\end{tabular}

*Correlation is significant at the 0.05 level (2-tailed). ${ }^{* *}$ Correlation is significant at the 0.01 level (2-tailed).

researchers (Li et al., 2013c; Guo et al., 2015). Our results showed that whether the paddy soil was Si-deficient or Si-enriched, the utilization of Si fertilizer could significantly $(p<0.05)$ improve the phytolith content of the rice organs (Tables 2, 3) such as the stem, sheath, leaf, grain and root. According to the formation mechanism of phytoliths, the available $\mathrm{Si}$ in the soil is taken up by rice plants at the roots, usually taking the shape of the plant cell or cell spatium where $\mathrm{Si}$ is deposited (Piperno, 1988; Ma, 2003; Neumann, 2003; Song et al., 2016). Thus, the use of Si fertilizer increased the content of effective Si in the soil (Ma et al., 2004; Liu et al., 2006; Cai, 2015) and increased the absorption capacity of $\mathrm{Si}$ in the rice ( $\mathrm{Li}$ et al., 2013c; Seyfferth et al., 2013; Guo et al., 2015; Zuo et al., 2016; Huan et al., 2018), thereby increasing the phytolith content of the rice plant (Table 4 ).

A substantial amount of research reported that the factors of the PhytOC content were as follows: different varieties (Parr et al., 2009, 2010; Parr and Sullivan, 2011; Li et al., 2013b; Song et al., 2017; Sun et al., 2017), pest and disease resistances (Ma et al., 2002), nitrogen utilization (Zhao et al., 2016), basalt powder (Guo et al., 2015), soil-effective Si content (Song et al., 2014b; Klotzbücher et al., 2018), and net production on the ground (Blecker et al., 2006). It has been shown that $\mathrm{Si}$ is an important element for rice growth and the deficiency of plantavailable Si may exert an adverse effect on the rice yield through biotic stresses, disease and pests, etc. (Ma, 2004; Ma et al., 2004). Our results also showed that the contents of phytolith in rice plants were different in Si-deficient and Si-enriched paddy soil. The content of Phytolith in rice plants with Si-enriched paddy soils was higher than that in rice plants with Si-deficient paddy soil (Tables 2, 4). Moreover, whether in Si-deficient or in Sienriched paddy soils, there was a positive correlation $(p<0.05)$ between the phytolith content of rice plants and the Si fertilizer dosages (Tables 5, 6). Previous studies have demonstrated that the content of the $\mathrm{Si}$ (phytoliths) in crops may be promoted through Si fertilizer application (Alvarez and Datnoff, 2001; Liang et al., 2010; Mecfel et al., 2010). Further, in the Si-deficient paddy soil, the estimated PhytOC fluxes were significantly related to the Si fertilizers $(R=0.973$ and $p<0.05)$, the phytolith content $(R=0.986$ and $p<0.05)$ and the biomass of the rice $(R=0.994$ and $p<0.01)$ (Table 5). However, in the Si-enriched paddy soil, the estimated PhytOC fluxes were not correlated $(P>0.05)$ with these factors. Zhang et al. (2014) showed that the yield of rice was increased $14.5 \%$ by the use of $225 \mathrm{~kg} \mathrm{ha}^{-1} \mathrm{Si}$ fertilizer; when the application of Si fertilizer was increased to $375 \mathrm{~kg} \mathrm{ha}^{-1}$, the yield of the rice increased only by $10.1 \%$. Similarly, Wu et al. also recommended the use of $225 \mathrm{~kg} \mathrm{ha}^{-1} \mathrm{Si}$ fertilizer as the most economical measure (Wu et al., 2014). We also obtained the same results. The application of Si fertilizer to the Si-enriched paddy soil did not increase the biomass of the rice but reduced it. In particular, when the amount of the Si fertilizer reached $600 \mathrm{~kg} \mathrm{ha}^{-1}$, the rice biomass decreased significantly by $29.10 \%$ compared with the control treatment (Table 4). Therefore, excessive Si fertilizer not only has no benefit to the accumulation of estimated PhytOC fluxes in rice plant, but also reduces the yield of rice. However, for Sideficient soils, the application of Si fertilizer can not only increase rice yield, but also increase the phytolith content of rice plants and the estimated PhytOC fluxes (Table 4). Thus, different Si fertilizer doses were one of the measures to improve the phytolith 
content and the biomass of the rice plant. Thus, how to promote the phytolith content and $\mathrm{C}$ content of phytoliths will require further in-depth study.

The global rice cultivation area was approximately $1.64 \times 10^{8}$ ha in 2014 (Prajapati et al., 2016); when rice is harvested, the rice straw and husks are removed from the paddy field and used for other purposes, including animal feeding and firewood, or simply incinerated (Savant et al., 1996). Thus, most of the Si taken up by rice is removed from a field when the rice straw is removed, and the loss of $\mathrm{SiO}_{2}$ is from 75 to $130 \mathrm{~kg} \mathrm{ha}^{-1}$ every production season (Zhang et al., 2014). Such large losses of Si make it difficult to maintain the balance of Si in soils from natural weathering alone. Appropriate dosages of Si fertilizer could solve the problem of Si deficiency in soil, and increase the biomass of rice and the content of phytolith in rice plants, and indeed result in the occlusion of increased $\mathrm{CO}_{2}$ in the rice plants (Liang et al., 2010; Mecfel et al., 2010). The estimated PhytOC fluxes increased from 0.49 to $4.52 \mathrm{Kg}$-e-CO $\mathrm{Ca}_{2} \mathrm{ha}^{-1}$ year $^{-1}$ (Table 4). More than $8.04 \times 10^{4}$ to $7.41 \times 10^{5}{\mathrm{Mg}-\mathrm{e}-\mathrm{CO}_{2}}$ would have been occluded within the phytolith of the rice plants per year globally. Taking the largest estimated PhytOC flux (12.93 $\mathrm{Kg}$-e- $\mathrm{CO}_{2} \mathrm{ha}^{-1}$ year $^{-1}$ ) of the rice plants, $2.12 \times 10^{6} \mathrm{Mg}-\mathrm{e}-\mathrm{CO}_{2}$, would have been occluded within the phytolith of rice plants every year. However, the annual $\mathrm{CO}_{2}$ bio-sequestration within the rice phytoliths of the unit area is likely to be lower than that of other plants, such as bamboo leaf litter $\left(1.56 \times 10^{7} \mathrm{Mg}\right.$-e$\mathrm{CO}_{2}$ year $\left.^{-1}\right)$ (Parr, 2006), wetland plants $\left(4.39 \times 10^{7} \mathrm{Mg}-\mathrm{e}-\mathrm{CO}_{2}\right.$ year ${ }^{-1}$ ) (Guo et al., 2015), grasslands $\left(4.14 \times 10^{7} \mathrm{Mg}\right.$-e- $\mathrm{CO}_{2}$ year $\left.^{-1}\right)$ (Song et al., 2012), millet $\left(2.37 \times 10^{6} \mathrm{Mg}\right.$-e-CO $_{2}$ year $\left.^{-1}\right)$ (Pan et al., 2017) and sugarcane leaf $\left(0.72 \times 10^{7} \mathrm{Mg}-\mathrm{e}-\mathrm{CO}_{2}\right.$ year $^{-1}$ ) (Parr et al., 2009). In this study, we showed that Si fertilizer application could promote the phytolith content and biomass of rice plants and further improve the estimated PhytOC flux of rice plants. Thus, the measure provided a theoretical basis for the bio-carbon sequestration of the rice plant and laid a foundation for PhytOC fixation in paddy soil by the return of straw.

\section{REFERENCES}

Alvarez, J., and Datnoff, L. E. (2001). The economic potential of silicon for integrated management and sustainable rice production. Crop Prod. 20, 43-48. doi: 10.1016/S0261-2194(00)00051-X

Anala, R., and Nambisan, P. (2015). Study of morphology and chemical composition of phytoliths on the surface of paddy straw. Paddy Water Environ. 13, 521-527. doi: 10.1007/s10333-014-0468-5

Blecker, S. W., Mcculley, R. L., Chadwick, O. A., and Kelly, E. F. (2006). Biologic cycling of silica across a grassland bioclimosequence. Glob. Biogeochem. Cycles 20, 4253-4274. doi: 10.1029/2006GB002690

Cai, D. (2015). Silicon fertilizer: a new resource-saving and environment-friendly fertilizer. China Agri Produc. News 6, 23.

Chadwick, K. M., Johnson, R. G., Dhaul, A. K., Steinmeyer, R. D., and Halm, R. L. (1994). Conversion of Direct Process High-Boiling Component to Chlorosilane Monomers in the Presence of Chlorine. Available at: https://patents.google.com/ patent/JPH0789709A/en (accessed Julu 16, 1993).

Clarke, J. (2003). The occurrence and significance of biogenic opal in the regolith. Earth Sci. Rev. 60, 175-194. doi: 10.1016/S0012-8252(02)00092-2

Epstein, E. (1994). The anomaly of silicon in plant biology. Proc. Natl. Acad. Sci. U.S.A. 91, 11-17. doi: 10.1073/pnas.91.1.11

\section{CONCLUSION}

The use of Si fertilizer could significantly increase the phytolith content of rice plants in Si-deficient red paddy soil or Si-enriched Wushan soil. The phytolith content of rice plants was positive correlation with the Si fertilizer dose in two types paddy soil. The estimated PhytOC fluxes in Si-deficient red paddy soil had a positive correlation with the phytolith content, the biomass of the rice and the Si fertilizer dose. In this study, we estimated that the PhytOC fluxes increased from 0.49 to $4.52 \mathrm{Kg}-\mathrm{e}-\mathrm{CO}_{2} \mathrm{ha}^{-1}$ year $^{-1}$. More than $8.04 \times 10^{4}$ to $7.41 \times 10^{5} \mathrm{Mg}$-e-CO $\mathrm{CO}_{2}$ would have been occluded within the phytoliths of the rice plants per year globally. Therefore, Si fertilizer application might provide a new approach to increase the atmospheric $\mathrm{CO}_{2}$ occluded within the phytoliths, offering a potential method.

\section{AUTHOR CONTRIBUTIONS}

All authors listed have made a substantial, direct, and intellectual contribution to the work. XS completed the experiments independently, carried out the data analysis, and finished the final writing of the article. QL made great contributions to guide the process of experiments. TT, XC, and XL helped in sampling, experimentation, and essay writing.

\section{FUNDING}

This work was partially supported by the National Natural Science Foundation of China (Nos. 41271208 and 31400464), the Anhui Province University Natural Science Research Foundation (Nos. KJ2017A423 and KJ2018A0430), the Excellent Researcher Program of the Education Department of Anhui Province (No. gxyq2018097) and the Laboratory Opening Subject of the School of Biology and Food Engineering of Chuzhou University (No. SWSP201816KF).

Guo, F., Song, Z., Sullivan, L., Wang, H., Liu, X., Wang, X., et al. (2015). phytolith carbon sequestration in rice ecosystems through basalt powder amendment. Sci. Bull. 60, 591-597. doi: 10.1007/s11434-015-0729-8

Henriet, C., Bodarwé, L., Dorel, M., Draye, X., and Delvaux, B. (2008). Leaf silicon content in banana (Musa spp.) reveals the weathering stage of volcanic ash soils in Guadeloupe. Plant Soil 313, 71-82. doi: 10.1007/s11104-008-9680-7

Hodson, M., White, P., Mead, A., and Broadley, M. (2005). Phylogenetic variation in the silicon composition of plants. Ann. Bot. 96, 1027-1046. doi: 10.1093/aob/ mci255

Huan, X., Lu, H., Zhang, J., and Wang, C. (2018). Phytolith assemblage analysis for the identification of rice paddy. Sci. Rep. 8:10932. doi: 10.1038/s41598-01829172-5

Ji, Z., Yang, X., Song, Z., Liu, H., Liu, X., Qiu, S., et al. (2017). Silicon distribution in meadow steppe and typical steppe of northern China and its implications for phytolith carbon sequestration. Grass Forage Sci. 73, 482-492. doi: 10.1111/gfs. 12316

Kameník, J., Mizera, J., and Øanda, Z. (2013). Chemical composition of plant silica phytoliths. Environ. Chem. Lett. 11, 189-195. doi: 10.1007/s10311-012-0396-9

Klotzbücher, T., Klotzbücher, A., Kaiser, K., Merbach, I., and Mikutta, R. (2018). Impact of agricultural practices on plant-available silicon. Geoderma 331, 15-17. doi: 10.1016/j.geoderma.2018.06.011 
Li, B., Song, Z., Li, Z., Wang, H., Gui, R., and Song, R. (2014). Phylogenetic variation of phytolith carbon sequestration in bamboos. Sci. Rep. 4:4710. doi: 10.1038 /srep04710

Li, Z., Song, Z., and Li, B. (2013a). The production and accumulation of phytolithoccluded carbon in Baiyangdian reed wetland of China. Appl. Geochem. 37, 117-124. doi: 10.1016/j.apgeochem.2013.07.012

Li, Z., Song, Z., Li, B., and Cai, Y. (2013b). Phytolith production in wetland plants of the Hangzhou Xixi Wetlands ecosystem. J. Zhejiang A F Univ. 30, 470-476.

Li, Z., Song, Z., Parr, J. F., and Wang, H. (2013c). Occluded C in rice phytoliths: implications to biogeochemical carbon sequestration. Plant Soil 370, 615-623. doi: $10.1111 / \mathrm{gcb} .12275$

Liang, Y., Haixia, H., Yong-Guan, Z., Jie, Z., Chunmei, C., and Volker, R. M. (2010). Importance of plant species and external silicon concentration to active silicon uptake and transport. New Phytol. 172, 63-72. doi: 10.1111/j.1469-8137.2006. 01797.x

Liu, M. D., Zhang, Y. L., Meng, X. F., Li, J., Yang, D., Wang, Y.-J., et al. (2006). Evaluation of silicon supply ing capac ity of paddy soil by silicon libera tion dynamics equation I the relationship between parameter of soil silicon liberation dynamics equation and relative yield. Chin. J. Soil Sci. 37, 107-110.

Ma, F., Namiki, M., Sakiko, N., Saeko, K., Kazunori, T., Takashi, I., et al. (2004). Characterization of the silicon uptake system and molecular mapping of the silicon transporter gene in rice. Plant Physiol. 136, 3284-3289. doi: 10.1104/pp. 104.047365

Ma, F. J. (2004). Role of silicon in enhancing the resistance of plants to biotic and abiotic stresses. Soil Sci. Plant Nutr. 50, 11-18. doi: 10.1080/00380768.2004. 10408447

Ma, J. F. (2003). Functions of Silicon in Higher Plants. Berlin: Springer. doi: 10.1007/ 978-3-642-55486-5_5

Ma, J. F., Kazunori, T., Masahiko, I., and Guo Feng, W. (2002). A rice mutant defective in Si uptake. Plant Physiol. 130, 2111-2117. doi: 10.1104/pp.010348

Ma, J. F., Tamai, K., Yamaji, N., Mitani, N., Konishi, S., Katsuhara, M., et al. (2006). A silicon transporter in rice. Nature 440, 688-691. doi: 10.1038/nature04590

Mecfel, J., Hinke, S., Goedel, W. A., Marx, G., Fehlhaber, R., Bäucker, E., et al. (2010). Effect of silicon fertilizer on silicon accumulation in wheat. J. Plant Nutr. Soil Sci. 170, 769-772. doi: 10.1016/j.envpol.2018.06.069

Neumann, D. (2003). Silicon in Plants. Berlin: Springer.

Pan, W., Song, Z., Liu, H., Zwieten, L. V., Li, Y., Yang, X., et al. (2017). The accumulation of phytolith-occluded carbon in soils of different grasslands. J. Soils Sediments 17, 1-8. doi: 10.1007/s11368-017-1690-8

Parr, J., Sullivan, L., Chen, B., Gongfu, Y. E., and Zheng, W. (2010). Carbon biosequestration within the phytoliths of economic bamboo species. Glob. Chang. Biol. 16, 2661-2667. doi: 10.1111/j.1365-2486.2009.02118.x

Parr, J., Sullivan, L., and Quirk, R. (2009). Sugarcane phytoliths: encapsulation and sequestration of a long-lived carbon fraction. Sugar Tech. 11, 17-21. doi: 10.1007/s12355-009-0003-y

Parr, J. F. (2006). Effect of fire on phytolith coloration. Geoarchaeol. Int. J. 21, 171-185. doi: 10.1002/gea.20102

Parr, J. F., and Sullivan, L. A. (2005). Soil carbon sequestration in phytoliths. Soil Biol. Biochem. 37, 117-124. doi: 10.1016/j.soilbio.2004.06.013

Parr, J. F., and Sullivan, L. A. (2011). Phytolith occluded carbon and silica variability in wheat cultivars. Plant Soil 342, 165-171. doi: 10.1007/s11104-010-0680-z

Pearsall, D. M. (1989). Paleoethnobotany. A Handbook of Procedures. Cambridge, MA: Academic Press, 1-470.

Piperno, D. R. (1988). Phytolith Analysis: An Archaeological and Geological Perspective. San Diego, CA: Academic Press.

Prajapati, K., Rajendiran, S., Coumar, V., Dotaniya, M. L., Kumar, A., Kundu, S., et al. (2016). Carbon occlusion potential of rice phytoliths: implications for global carbon cycle and climate change mitigation. Appl. Ecol. Environ. Res. 14, 265-281. doi: 10.15666/aeer/1402_265281

Savant, N. K., Snyder, G. H., and Datnoff, L. E. (1996). Silicon management and sustainable rice production. Adv. Agron. 58, 151-199. doi: 10.1016/S00652113(08)60255-2
Seyfferth, A. L., Kocar, B. D., Lee, J. A., and Fendorf, S. (2013). Seasonal dynamics of dissolved silicon in a rice cropping system after straw incorporation. Geochim. Cosmochim. Acta 123, 120-133. doi: 10.1016/j.gca.2013.09.015

Si, Y., Wang, L., Zhou, Q., and Huang, X. (2018). Effects of lanthanum and silicon stress on bio-sequestration of lanthanum in phytoliths in rice seedlings. Environ. Sci. Pollut. Res. 25, 10752-10770. doi: 10.1007/s11356-018-1360-4

Song, Z., Liu, H., Li, B., and Yang, X. (2013). The production of phytolith-occluded carbon in China's forests: implications to biogeochemical carbon sequestration. Glob. Chang. Biol. 370, 615-623. doi: 10.1111/gcb.12275

Song, Z., Liu, H., Si, Y., and Yin, Y. (2012). The production of phytoliths in China's grasslands: implications to the biogeochemical sequestration of atmospheric CO2. Glob. Chang. Biol. 18, 3647-3653. doi: 10.1111/gcb.12017

Song, Z., Liu, H., Strömberg, C., Yang, X., and Zhang, X. (2017). Phytolith carbon sequestration in global terrestrial biomes. Sci. Total Environ. 603-604, 502-509. doi: 10.1016/j.scitotenv.2017.06.107

Song, Z., Mcgrouther, K., and Wang, H. (2016). Occurrence, turnover and carbon sequestration potential of phytoliths in terrestrial ecosystems. Earth Sci. Rev. 158, 19-30. doi: 10.1016/j.earscirev.2016.04.007

Song, Z., Müller, K., and Wang, H. (2014a). Biogeochemical silicon cycle and carbon sequestration in agricultural ecosystems. Earth Sci. Rev. 139, 268-278. doi: 10.1016/j.scitotenv.2017.06.107

Song, Z., Wang, H., Strong, P. J., and Guo, F. (2014b). Phytolith carbon sequestration in China's croplands. Eur. J. Agron. 53, 10-15. doi: 10.1016/j.eja. 2013.11.004

Sun, X., Liu, Q., Zhao, G., Chen, X., Tang, T., and Xiang, Y. (2017). Comparison of phytolith-occluded carbon in 51 main cultivated rice (Oryza sativa) cultivars of China. RSC Adv. 7, 54726-54733. doi: 10.1039/C7RA10685H

Sun, X., Qin, L., Xiang, C., and Keya, Z. (2016). Evaluation of the occluded carbon within husk phytoliths of 35 rice cultivars. Front. Earth Sci. 10:683-690. doi: 10.1007/s11707-015-0549-9

Wang, Y. J. (1998). A study on the chemical compostion of phytolths. J. Oceano Huanghai Bohai Seas. 16, 33-38.

Wen, C., Lu, H., Zuo, X., and Ge, Y. (2018). Advance of research on modern soil phytolith. Sci. China Earth Sci. 61, 1-14. doi: 10.1007/s11430-017-9220-8

Wu, H.-B., Shen, J.-N., and Hu, S.-S. (2014). Effect of silicon on plant traits and yield of cold region rice. North Rice 44, 12-15.

Yang, X., Song, Z., Liu, H., Bolan, N. S., Wang, H., and Li, Z. (2015). Plant silicon content in forests of north China and its implications for phytolith carbon sequestration. Ecol. Res. 30, 347-355. doi: 10.1007/s11284-014-1228-0

Zhang, L., Chen, X., Chang, B., Gu, X., Li, W., Wang, S., et al. (2014). Application effect of silicon fertilizer on rice. Heilongjiang Agric. Sci. 12, 43-46. doi: 10.1007/ s11356-017-0753-0

Zhao, Y., Song, Z., Xu, X., Liu, H., Wu, X., Li, Z., et al. (2016). Nitrogen application increases phytolith carbon sequestration in degraded grasslands of North China. Ecol. Res. 31, 117-123. doi: 10.1007/s11284-015-1320-0

Zuo, X., and Lü, H. (2011). Carbon sequestration within millet phytoliths from dryfarming of crops in China. Sci. Bull. 56, 3451-3456. doi: 10.1007/s11434-0114674-X

Zuo, X., Lu, H., Li, Z., Song, B., Xu, D., Zou, Y., et al. (2016). Phytolith and diatom evidence for rice exploitation and environmental changes during the early midHolocene in the Yangtze Delta. Quat. Res. 86, 304-315. doi: 10.1016/j.yqres. 2016.08.001

Conflict of Interest Statement: The authors declare that the research was conducted in the absence of any commercial or financial relationships that could be construed as a potential conflict of interest.

Copyright (c) 2019 Sun, Liu, Tang, Chen and Luo. This is an open-access article distributed under the terms of the Creative Commons Attribution License (CC BY). The use, distribution or reproduction in other forums is permitted, provided the original author(s) and the copyright owner(s) are credited and that the original publication in this journal is cited, in accordance with accepted academic practice. No use, distribution or reproduction is permitted which does not comply with these terms. 